\title{
UPAYA MENINGKATKAN KEMAMPUAN MENGGUNAKAN PROGRAM MICROSOFT OFFICE 365 MELALUI PRAKTIK UNJUK KERJA PADA GURU SD
}

\author{
Sri Hartini \\ SD Negeri 4 Balepanjang \\ Email: srihartinigro@gmail.com
}

\begin{abstract}
Abstrak
Penelitian ini bertujuan untuk meningkatkan kemampuan guru SD dalam menggunakan program Microsoft Office 365 sebagai media pembelajaran melalui praktik unjuk kerja. Penelitian menggunakan bentuk Penelitian Tindakan Sekolah (PTS) yang dilaksanakan dalam 2 (dua) siklus. Penelitian ini dilaksanakan di SDN 4 Balepanjang dengan subjek penelitian sebanyak 8 orang guru. Metode penelitian menggunakan Penelitian Tindakan Sekolah. Penilaian kemampuan guru dilakukan dengan teknik observasi dengan lembar observasi. Validasi data dilakukan dengan teknik triangulasi. Analisis data dilakukan dengan teknik analisis deskriptip komparatif. Dari data empiris hasil penelitian diperoleh fakta bahwa melalui praktik unjuk kerja dapat meningkatkan praktik unjuk kerja dapat meningkatkan kemampuan guru SDN 4 Balepanjang Tahun Pelajaran 2019/2020 dalam menggunakan program Microsoft Office 365 sebagai media pembelajaran. Sehingga dapat disimpulkan bahwa praktik unjuk kerja dapat meningkatkan kemampuan guru SDN 4 Balepanjang Tahun Pelajaran 2019/2020 dalam menggunakan program Microsoft Microsoft Office 365 sebagai media pembelajaran. Kata kunci: kemampuan guru, Microsoft Office 365, praktik unjuk kerja
\end{abstract}

\begin{abstract}
This study aims to improve the ability of elementary school teachers to use Microsoft Office 365 programs as learning media through performance practices. The study used the form of School Action Research (PTS) which was carried out in 2 (two) cycles. This research was conducted at SDN 4 Balepanjang with research subjects as many as 8 teachers. The research method uses School Action Research. The teacher's ability assessment is carried out by using observation techniques with observation sheets. Data validation is done by triangulation technique. Data analysis was carried out using comparative descriptive analysis techniques. From the empirical data of the research results, it is found that through performance practices, improving performance practices can improve the ability of SDN 4 Balepanjang teachers in the 2019/2020 academic year in using the Microsoft Office 365 program as a learning medium. So it can be concluded that performance practices can improve the ability of SDN 4 Balepanjang teachers for the 2019/2020 academic year in using the Microsoft Microsoft Office 365 program as a learning medium.
\end{abstract}

Keywords: teacher ability, Microsoft Office 365, performance practice

\section{PENDAHULUAN}

Kegiatan proses belajar mengajar sering ditemukan adanya kesulitan kesulitan dari segi interaksi dalam menyampaikan bahan kepada siswa (Nurgiansah, 2019) (Nurgiansah, 2020d). Hal ini bisa terjadi karena intelegensi dan daya tangkap siswa yang berbeda-beda atau kurang jelasnya keterangan dari guru, baik dari segi suara, tulisan maupun juga dikarenakan guru kurang profesional dalam menggunakan metode mengajar dan media pembelajaran (Febriani, 2019) (Khotidjah, 2021) (Murniyati, 2021).
Penggunaan media pembelajaran yang tepat mempunyai manfaat yang besar sesuai dengan kegiatan pembelajaran (Ngatmiyatun, 2021) (Pitoyo, 2021) (Priyastuti, 2021).

Media pembelajaran penting dalam proses pembelajaran, adanya media mendukung proses komunikasi yang dilakukan oleh guru sehingga dapat optimal (Rahmelia, 2021)(S et al., 2021)(Sakinah \& Dewi, 2021)(Sakti \& Hartanto, 2020). Media pembelajaran yang dimaksud adalah alat bantu dalam mengajar untuk menyalurkan informasi 
dari guru kepada peserta didik sehingga dapat merangsang pikiran, perasaan, perhatian dan semangat peserta didik untuk belajar. Penggunaan media merupakan bagian yang perlu diperhatikan guru dalam kegiatan pembelajaran (Saptaningsih \& Astuti, 2019) (Sigit \& Andari, 2019) (Sumarni, 2021)(Widodo, 2021). Namun pada kenyataannya media pembelajaran masih kurang diperhatikan (Nurgiansah, 2020b).

Hal yang terlihat sekarang, masih banyak guru kurang mampu menggunakan media pengajaran yang tersedia di sekolah, misalnya pembelajaran hanya dititikberatkan pada penguasaan bidang materi saja sedangkan di bidang pengalaman kurang terpenuhi (Nurgiansah, 2020a). Dalam pengajaran di sekolah dasar dengan konsep tematik pun media sangat diperlukan sebagai alas untuk membantu seorang guru dalam memberikan suatu penjelasan, baik itu bersifat kongkrit, maupun abstrak (Nurgiansah, 2021b). Akan tetapi dalam penggunaan media ini diperlukan suatu keterampilan dan kekreatifan yang dituntut pada seorang guru untuk menggunakan berbagai media, terutama sarana dan prasarana, yang dimiliki oleh sekolah serta pemanfaatan lingkungan sebagai media dalam proses belajar mengajar (Nurgiansah, 2021c)(Nurgiansah, 2021a)(Nurgiansah, 2021e).

Sebagaimana yang dijelaskan oleh Usman dan Lilis (2001: 4) dalam (Nurgiansah, 2021f) (Rachman et al., 2021) (Dewantara \& Nurgiansah, 2021b) (Dewantara \& Nurgiansah, 2021a) bahwa penggunaan media di suatu pendidikan merupakan dasar yang sangat penting dan diperlukan yang bersifat melengkapi dan merupakan bagian integral demi berhasilnya proses pendidikan dan pengajaran di sekolah. Untuk mencapai tujuan pendidikan tersebut diperlukan peningkatan kualitas sumber daya manusia (SDM) dan kualitas proses pembelajaran.
Salah satu faktor yang mempengaruhi keberhasilan dalam proses pembelajaran adalah penggunaan media pembelajaran, baik benda-benda asli maupun tiruan yang relevan dengan konsep (Nurgiansah, Pratama, et al., 2021). Disamping media pembelajaran yang merupakan salah satu sumber belajar yang penting, media pembelajaran juga dapat membantu para guru untuk memperjelas dan memvisualisasikan konsep kepada para peserta didik dalam mencapai ketrampilan tertentu (Nurgiansah, Hendri, et al., 2021) (Nurgiansah, 2020c) (Nurgiansah, 2021d). Sejalan dengan perkembangan zaman dapat ditandai dengan kemajuan ilmu pengetahuan dan tehnologi canggih. Karena itu dalam proses belajar mengajar perlu juga dikembangkan cara cara mengajar yang baru. Diantaranya yaitu cara mengajar dengan menggunakan media komputer dan salah satunya pengoperasian Microsoft Office 365 (Nurgiansah \& Sukmawati, 2020) (Nurgiansah \& Pringgowijoyo, 2020).

Berdasarkan pengamatan awal yang penulis lakukan di SD Negeri 4 Balepanjang Tahun Pelajaran 2019/2020 maka penulis menemukan masalah-masalah para guru SD Negeri 4 Balepanjang sebagai berikut: 1) Kemampuan para guru dalam menggunakan Microsoft Office 365 sebagai media pembelajaran masih rendah; 2) Kualitas proses pembelajaran dengan menggunakan media Microsoft Office 365 pembelajaran yang sudah dibuat oleh guru masih belum optimal; dan 3) Para guru kurang termotivasi dan belum percaya diri dalam menggunakan Microsoft Office 365 sebagai media pembelajaran. Sedangkan secara empiris diperoleh fakta bahwa tidak ada guru yang kemampuanya masuk kualifikasi Amat Baik, hanya 2 orang guru $(25,0 \%)$ yang kualifikasinya Baik, ada 4 orang guru $(50,0 \%)$ yang kualifikasinya Cukup dan masih ada 2 orang guru $(25,0 \%)$ yang kualifikasinya Kurang. 
Permasalahan

rendahnya kemampuan guru SD Negeri 4 Balepanjang Tahun Pelajaran 2019/2020 dalam menggunakan Microsoft Office 365 sebagai media pembelajaran akan berpengaruh terhadap perbaikan kualitas proses pembelajaran. Karena dalam beberapa mata pembelajaran, banyak menggunakan ilustrasi gambar, grafik, konsep yang harus ditampilkan secara visual dalam proses pembelajarannya. Sehingga sangat sulit jika hanya dijelaskan dengan metode ceramah.

Berdasarkan fakta tersebut, maka penulis berencana untuk melaksanakan suatu Penelitian Tindkdan Sekolah (PTS) melalui Bentuk upaya peningkatan yang digunakan dalam penelitian tindakan (action research) ini adalah praktik unjuk kerja. Metode praktik unjuk kerja adalah suatu metode dengan memberikan materi pendidikan baik menggunakan alat atau benda, seperti diperagakan, dengan harapan peserta didik menjadi jelas dan mudah sekaligus dapat mempraktikkan materi yang dimaksud suatu saat di masyarakat. Metode ini memberikan jalan kepada para peserta didik untuk menerapkan, menguji dan menyesuaikan teori dengan kondisi sesungguhnya melalui praktik peserta praktik atau latihan akan mendapatkan pelajaran yang sangat baik untuk mengembangkan dan menyempurnakan keterampilan yang diperlukan ( $R$. Ceha, dkk., 2016: 18).

Berdasarkan uraian di atas, maka penulis akan melaksanakan satu Penelitian Tindkan Sekolah (PTS) yang berjudul "Upaya Meningkatkan Kemampuan Guru Dalam Menggunakan Program Microsoft Office 365 Sebagai Media Pembelajaran Melalui Praktik Unjuk Kerja Di SD Negeri 4 Balepanjang Tahun Pelajaran 2019/2020 ".

\section{METODE PENELITIAN}

Penelitian tindakan kelas ini dilaksanakan pada semester 1 tahun pelajaran 2019/2020 selama empat bulan. Penelitian dimulai bulan Juli 2019 hingga bulan September 2019. Lokasi tempat penelitian adalah di SD Negeri 4 Balepanjang yang beralamat di Balepanjang, Kecamatan Baturetno, Kabupaten Wonogiri. Alasan pemilihan tempat penelitian ini adalah karena peneliti melihat adanya indikasi rendahnya kemampuan guru SD Negeri 4 Balepanjang Tahun Pelajaran 2019/2020 dalam menggunakan program Microsoft Office 365 sebagai media pembelajaran. Kedudukan peneliti dalam penelitian ini adalah selaku pelaksana tindakan serta pengumpul data.

Subjek penelitian ini adalah guru SD Negeri 4 Balepanjang Tahun Pelajaran 2019/2020 dengan jumlah 8 orang. Sedangkan objek penelitian ini adalah kemampuan guru SD Negeri 4 Balepanjang Tahun Pelajaran 2019/2020 dalam menggunakan program Microsoft Office 365 sebagai media pembelajaran melalui pelatihan dan simulasi. Banyaknya data dalam penelitian ini ada tiga macam yaitu: a) Data hasil penilaian kemampuan guru pada kondisi awal sebelum pelaksanaan PTS, b) Data hasil penilaian kemampuan guru pada siklus I, dan c) Data hasil penilaian kemampuan guru pada siklus II.

Analisis data kemampuan guru dalam menggunakan program Microsoft Office 365 sebagai media pembelajaran pada kondisi awal, siklus I dan siklus II dilakukan dengan menggunakan analisis deskriptif komparatif. Analisis deskriptif komparatif dilakukan pada siklus I dan siklus II. Analisis data siklus I dilakukan dengan membandingkan hasil penilaian kemampuan guru kondisi awal dengam nilai hasil penilaian kemampuan guru pada siklus I. Sedangkan analisis data siklus II dilakukan dengan membandingkan hasil penilaian kemampuan guru pada siklus I dengan hasil penilaian kemampuan guru pada siklus II.

Keberhasilan suatau penelitian dapat dilihat dari pencapaian indikator kinerja. Indikator kerja dapat dilihat secara 
umum dengan membandingkan hasil penilaian kemampuan guru dari satu siklus ke siklus berikutnya. Indikator kinerja penelitian ini adalah sebagai berikut: 1) Adanya peningkatan kemampuan guru dalam menggunakan program Microsoft Office 365 sebagai media pembelajaran dari kondisi awal ke siklus I, dan dari siklus I ke siklus II. 2) Semua guru SD Negeri 4 Balepanjang kemampuan dalam menggunakan program Microsoft Office 365 sebagai media pembelajaran minimal mencapai kualifikasi Baik. Selanjutnya, kualifikasi penilaian kemampuan guru dalam menggunakan program Microsoft Office 365 sebagai media pembelajaran adalah sebagai berikut.

Tabel 1

Kualifikasi Penilaian Kemampuan Guru

\begin{tabular}{|c|c|c|}
\hline No & Kualifikasi & Range Nilai \\
\hline 1 & Amat Baik & $91-100$ \\
\hline 2 & Baik & $71-90$ \\
\hline 3 & Cukup & $51-70$ \\
\hline 4 & Kurang & $\leq 50$ \\
\hline
\end{tabular}

\section{HASIL PENELITIAN DAN PEMBAHASAN Hasil Penelitian}

Deskripsi Kondisi Awal

Hasil observasi kondisi awal menunjukkan bahwa: 1) kemampuan guru SD Negeri 4 Balepanjang Tahun Pelajaran 2019/2020 dalam menggunakan program Microsoft Office 365 sebagai media pembelajaran masih rendah; 2) Kualitas proses pembelajaran dengan menggunakan media Microsoft Office 365 pembelajaran yang sudah dibuat oleh guru masih belum optimal; dan 3) Para guru kurang termotivasi dan belum percaya diri dalam menggunakan slide Microsoft PowerPoint sebagai media pembelajaran. Sedangkan secara empiris diperoleh fakta hasil penilaian kemampuan guru SD Negeri 4 Balepanjang Tahun Pelajaran 2019/2020 dalam menggunakan program Microsoft Office 365 sebagai media pembelajaran sebagai berikut.
Tabel 2

Kemampuan Guru pada Kondisi Awal

\begin{tabular}{|c|c|c|}
\hline No & Predikat & Jumlah Guru (\%) \\
\hline 1 & Amat Baik & - \\
2 & Baik & 2 orang $(25,0 \%)$ \\
3 & Cukup & 4 orang $(50,0 \%)$ \\
4 & Kurang & 2 orang $(25,0 \%)$ \\
\hline & Rata-rata & $\mathbf{5 9 , 5}$ \\
& Predikat & Cukup \\
\hline
\end{tabular}

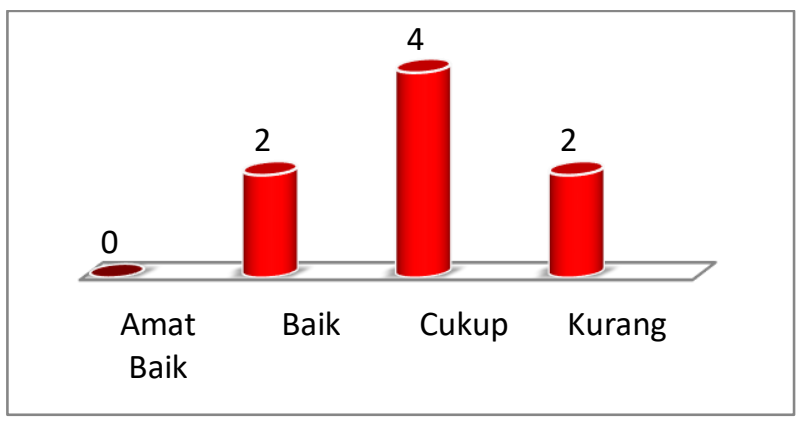

Gambar 1

Grafik Kemampuan guru pada Kondisi Awal

Dari data di atas menunjukkan bahwa pada kondisi awal, tidak ada guru yang kemampuanya masuk kualifikasi Amat Baik, hanya 2 orang guru $(25,0 \%)$ yang kualifikasinya Baik, ada 4 orang guru (50,0\%) yang kualifikasinya Cukup dan masih ada 2 orang guru $(25,0 \%)$ yang kualifikasinya Kurang. Nilai rata-rata kemampuan guru dalam menggunakan Microsoft Office 365 sebagai media pembelajaran adalah 59,5 masuk kualifikasi Cukup. Mengetahui adanya permasalahan rendahnya kemampuan guru SD Negeri 4 Balepanjang Tahun Pelajaran 2019/2020 dalam menggunakan program Microsoft Office 365 sebagai media pembelajaran, maka penulis sebagai Kepala SD Negeri 4 Balepanjang berencana untuk melaksanakan Penelitian Tindakan Sekolah (PTS) melalui praktik unjuk kerja.

\section{Pembahasan}

Siklus I

Hasil pengamatan terhadap aktivitas guru peserta praktik unjuk kerja pada siklus I, diperoleh data kemampuan 
guru SD Negeri 4 Balepanjang Tahun Pelajaran 2019/2020 dalam menggunakan program Microsoft Office 365 sebagai media pembelajaran sebagai berikut.

Tabel 3

Kemampuan Guru pada Siklus I

\begin{tabular}{|c|c|c|}
\hline No & Predikat & Jumlah Guru (\%) \\
\hline 1 & Amat Baik & 1 orang (12,5\%) \\
2 & Baik & 3 orang (37,5\%) \\
3 & Cukup & 4 orang (50,0\%) \\
4 & Kurang & - \\
\hline \multicolumn{2}{|c|}{ Rata-rata } & 70,3 \\
& Predikat & Cukup \\
\hline
\end{tabular}

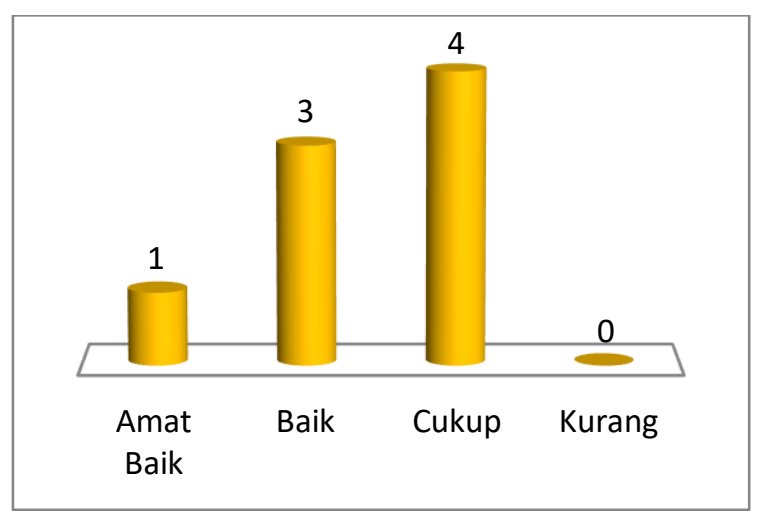

Gambar 2

Grafik Kemampuan Guru pada Siklus I

Pada pelaksanaan tindakan siklus I ada 1 orang $(12,5 \%)$ yang kemampuannya masuk kualifikasi Amat Baik, 3 orang guru $(37,5 \%)$ yang kemampuannya masuk kualifikasi Baik, sebanyak 4 orang guru (50,0\%) yang kemampuannya masuk kualifikasi Cukup dan tidak ada yang kemampuannya masuk kualifikasi Kurang. Nilai rata-rata kemampuan guru dalam menggunakan Microsoft Office 365 sebagai media pembelajaran adalah 70,3 masuk kualifikasi Cukup. Mengacu pada hasil tersebut, kemampuan guru SD Negeri 4 Balepanjang pada siklus I sudah meningkat, namun peningkatannya belum memenuhi indikator kinerja penelitian ini. Sehingga, peneliti memutuskan meneruskan tindakan ke siklus II dengan melaksanakan praktik unjuk kerja secara kelompok dengan pendampingan intensif.
Siklus II

Pada siklus II, peneliti melaksanakan praktik unjuk kerja secara kelompok dengan pendampingan intensif. Hasil penilaian kemampuan guru SD Negeri 4 Balepanjang Tahun Pelajaran 2019/2020 dalam menggunakan Microsoft Office 365 sebagai media pembelajaran pada siklus II diperoleh data sebagai berikut.

Tabel 4

Kemampuan Guru pada Siklus II

\begin{tabular}{|c|c|c|}
\hline No & Predikat & Jumlah Guru (\%) \\
\hline 1 & Amat Baik & 2 orang (25,0\%) \\
2 & Baik & 6 orang (75,0\%) \\
3 & Cukup & - \\
4 & Kurang & - \\
\hline \multicolumn{2}{|c|}{ Rata-rata } & 81,1 \\
\multicolumn{2}{|c|}{ Predikat } & Baik \\
\hline
\end{tabular}

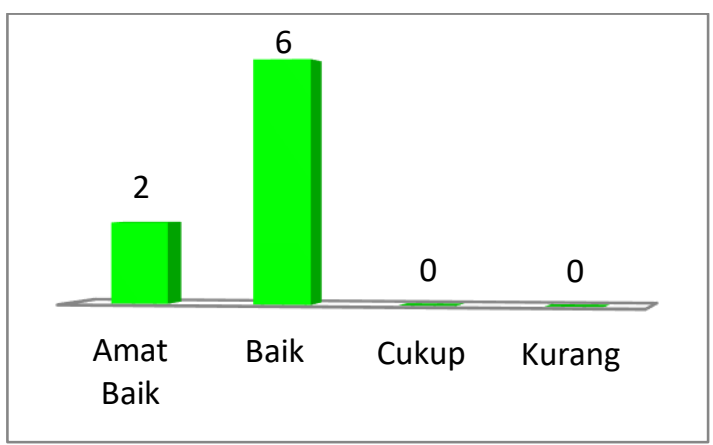

Gambar 3

Grafik Kemampuan Guru pada Siklus II

Pada siklus II peneliti melaksanakan tindakan penelitian melalui praktik unjuk kerja secara kelompok dengan pendampingan intensif. Pada siklus II ada 2 orang guru $(25,0 \%)$ yang kemampuannya masuk kualifikasi Amat Baik, sebanyak 6 orang guru $(75,0 \%)$ yang kemampuannya masuk kualifikasi Baik, dan tidak ada guru yang kemampuannya masuk kualifikasi Cukup maupun Kurang. Nilai rata-rata kemampuan guru SD Negeri 4 Balepanjang dalam menggunakan Microsoft Office 365 sebagai media pembelajaran adalah 81,1 masuk kualifikasi Baik. Peningkatan kemampuan guru SD Negeri 4 Balepanjang dalam menggunakan Microsoft Office 365 
sebagai media pembelajaran pada siklus II sudah berhasil mencapai semua indikator kinerja penelitian.

\section{KESIMPULAN}

Mengacu pada data empiris hasil penelitian diperoleh fakta bahwa melalui praktik unjuk kerja dapat meningkatkan praktik unjuk kerja dapat meningkatkan kemampuan guru SD Negeri 4 Balepanjang Tahun Pelajaran 2019/2020 dalam menggunakan program Microsoft Office 365 sebagai media pembelajaran. Dari kondisi awal tidak ada guru yang kemampuannya Amat Baik dan hanya 2 orang guru $(25,0 \%)$ yang kualifikasinya Baik dengan nilai ratarata kompetensi guru hanya 59,5 (Cukup).
Meningkat pada siklus I menjadi ada 1 orang $(12,5 \%)$ yang kemampuannya Amat Baik dan 3 orang guru $(37,5 \%)$ yang kemampuannya Baik dengan nilai rata-rata kompetensi guru adalah 70,3 (Cukup). Meningkat lagi pada siklus II menjadi 2 orang guru $(25,0 \%)$ yang kemampuannya Amat Baik dan sebanyak 6 orang guru $(75,0 \%)$ yang kemampuannya Baik dengan nilai rata-rata kompetensi guru 81,1 (Baik). Dapat disimpulkan bahwa melalui praktik unjuk kerja dapat meningkatkan kemampuan guru SD Negeri 4 Balepanjang Tahun Pelajaran 2019/2020 dalam menggunakan program Microsoft Microsoft Office 365 sebagai media pembelajaran.

\section{DAFTAR PUSTAKA}

Arif S. Sadiman, dkk. 2011. Media Pendidikan, Pengertian, Pengembangan, dan Pemanfaatannya. Jakarta: PT. Raja Grafindo Persada.

Arikunto, Suharsimi. 2006. Penelitian Tindakan Kelas. Jakarta: Rosdakarya

Daryanto. 2011. Penelitian Tindakan Kelas dan Penelitian Tindakan Sekolah. Yogyakarta: GAVA MEDIA.

Depdiknas. 2005. Peraturan Pemerintah (PP) Nomor 74 Tahun 2008 tentang Guru dan Dosen

Dewantara, J. A., \& Nurgiansah, T. H. (2021a). Peningkatan Keaktifan Belajar Melalui Penerapan Model Picture And Picture Dalam Pembelajaran PPKn di Sekolah Dasar. Jurnal Publikasi Pendidikan, 11(3), 234-241.

Dewantara, J. A., \& Nurgiansah, T. H. (2021b). Strengthening Pancasila Values During the Covid-19 Pandemic. Edukatif: Jurnal Ilmu Pendidikan, 3(4), 2411-2417.

Dina Indriana. 2011. Ragam Alat Bantu Media Pengajaran. Jogjakarta: Diva Perss.

Fathurrohman, Pupuh. \& Sutikno M. Sobri. 2008. Strategi Belajar Mengajar. Bandung: PT Refika Aditama

Febriani, N. W. (2019). Pendekatan Saintifik Sebagai Konsep Dasar Pembelajaran Siswa di Sanggar Anak Alam (SALAM) Nitiprayan Yogyakarta. Jurnal Kewarganegaraan, 3(1), 3540.

Fitriyani, R. Jaenudin, \& S. Fatimah. 2013. Pengaruh Penilaian Unjuk Kerja terhadap Sikap Peserta Didik pada Mata Pelajaran Ekonomi di SMA Srijaya Negara Palembang. Jurnal Pendidikan \& Kajian Sejarah. 3(4): 23-28.

J.B Situmorang dan Winarno, 2008. Pendidikan Profesi dan Sertifikasi Pendidik. Klaten: Macanan Jaya Cemerlang

Jamil Suprihatiningkrum, 2014. Guru Profesional: Pedoman Kinerja, Kualifikasi \& Kompetensi Guru. Yogyakarta: Ar-Ruzz Media

Jejen Musfah, 2012. Peningkatan Kompetensi Guru: Melalaui Pelatihan dan Sumber Belajar Teori dan Praktik, Jakarta: Kencana

Khotidjah, D. (2021). Peningkatan Penggunaan Past Tense Dalam Text Recount Melalui Model STAD pada Siswa. Jurnal Kewarganegaraan, 5(1), 86-91.

Mulyasa, E. 2013. Standar Kompetensi dan Sertifikasi Guru, Bandung: PT Remaja Rosdakarya 
Murniyati, M. (2021). Peningkatan Kemampuan Menyusun Rpp Pembelajaran Kooperatif Melalui Program Supervisi Akademik Bagi Guru Kelas. Jurnal Kewarganegaraan, 5(1), $71-$ 76. https://journal.upy.ac.id/index.php/pkn/article/view/1330

Ngatmiyatun, B. (2021). Peningkatan Kemampuan Penggunaan Microsoft Office 365 Melalui Pelatihan Dan Simulasi Pada Guru Sekolah Dasar. Jurnal Kewarganegaraan, 5(1), 77-85.

Nurgiansah, T. H. (2019). Pemutakhiran Kurikulum Pendidikan Kewarganegaraan di Era Revolusi Industri 4.0. Prosiding Seminar Kewarganegaraan Universitas Negeri Medan, 1(1), 95-102.

Nurgiansah, T. H. (2020a). Build An Attitude of Nationalism Students At SDN 7 Kadipaten With The Method of Discusion In The Subject PPKn. Jurnal Serunai Pendidikan Pancasila Dan Kewarganegaraan STKIP Budi Daya Binjai, 9(1), 1-11.

Nurgiansah, T. H. (2020b). Fenomena Prostitusi Online Di Kota Yogyakarta Dalam Persfektif Nilai Kemanusiaan Yang Adil Dan Beradab. Jurnal Kewarganegaraan, 17(1), 27-34. https://doi.org/10.24114/jk.v17i1.14208

Nurgiansah, T. H. (2020c). Filsafat Pendidikan. In Banyumas: CV Pena Persada.

Nurgiansah, T. H. (2020d). Pelatihan Penulisan Artikel Ilmiah Bagi Mahasiswa PPKn Universitas PGRI Yogyakarta. JNPM: Jurnal Nasional Pengabdian Masyarakat, 1(1), 16-23.

Nurgiansah, T. H. (2021a). Partisipasi Politik Masyarakat Sleman di Masa Pandemi Covid-19 dalam Konteks Pendidikan Kewarganegaraan. Jurnal Civic Hukum, 6(1), 1-9.

Nurgiansah, T. H. (2021b). Pelatihan Penelitian Tindakan Kelas Bagi Guru Pendidikan Kewarganegaraan Di Sekolah Menengah Atas Se-Kabupaten Bantul. BERNAS: Jurnal Pengabdian Kepada Masyarakat, 2(1), 28-33. https://doi.org/10.31949/jb.v2i1.566

Nurgiansah, T. H. (2021c). Pemanfaatan E-Learning Dalam Pembelajaran Pendidikan Kewarganegaraan. JINTECH: Journal of Information Technology, 2(2), 138-146.

Nurgiansah, T. H. (2021d). Pendidikan Pancasila. In Solok: CV Mitra Cendekia Media.

Nurgiansah, T. H. (2021e). Petuah Pendidikan Kewarganegaraan Dalam Kontestasi Politik. AoEJ: Academy of Education Journal, 12(1), 39-47.

Nurgiansah, T. H. (2021f). The Role of Citizenship Education in Building Bantul Community Political Participation in The Pandemic Covid 19. Prosiding Seminar Nasional Pendidikan Dan Kewirausahaan, 4(1), 1-4.

Nurgiansah, T. H., Hendri, \& Khoerudin, C. M. (2021). Role Playing Dalam Pembelajaran Pendidikan Pancasila dan Kewarganegaraan. Jurnal Kewarganegaraan, 18(1), 56-64. https://doi.org/10.24114/jk.v18i1.22597

Nurgiansah, T. H., Pratama, F. F., \& Iman, A. S. (2021). Penelitian Tindakan Kelas Dalam Pendidikan Kewarganegaraan. Jurnal Pendidikan Pancasila Dan Kewarganegaraan, 2(1), 10-23.

Nurgiansah, T. H., \& Pringgowijoyo, Y. (2020). Pelatihan Penggunaan Model Pembelajaran Jurisprudensial Pada Guru Di KB TK Surya Marta Yogyakarta. KUAT: Keuangan Umum Dan Akuntansi Terapan. PKNSTAN, 2(1).

Nurgiansah, T. H., \& Sukmawati. (2020). Tantangan Guru Pendidikan Kewarganegaraan Di Masa Adaptasi Kebiasaan Baru. Jurpis: Jurnal Pendidikan Ilmu Sosial, 17(2), 139-149.

Pitoyo, S. J. (2021). Upaya Meningkatkan Kompetensi Penyusunan RPP Berkarakter Melalui Praktik Unjuk Kerja. Jurnal Kewarganegaraan, 5(1), 120-126.

Priyastuti, K. E. (2021). Upaya Meningkatkan Hasil Belajar Siswa Menggunakan Metode Snowball Throwing. Jurnal Kewarganegaraan, 5(1), 92-100.

Rachman, F., Nurgiansah, T. H., \& Kabatiah, M. (2021). Profilisasi Pendidikan Kewarganegaraan dalam Kurikulum Pendidikan Indonesia. Edukatif: Jurnal Ilmu Pendidikan, 3(5), 2970-2984. 
Rahmelia, S. (2021). Pemaknaan Mahasiswa Terhadap Narasi Konflik Beragama. Jurnal Kewarganegaraan, 5(1), 45-54.

R. Ceha, Endang Prasetyaningsih, Iyan Bachtiar, dan Agus Nana S. 2016. Peningkatan Kemampuan Guru Dalam Pemanfaatan Teknologi Informasi Pada Kegiatan Pembelajaran. Jurnal Managemen Pendidikan - Vol. 13, No. 1, Januari 2016: 1-14

S, H. C., Alamsyah, M., Izzrufi, M. I., L, S. R., \& Saepudin, E. (2021). Persepsi Mahasiswa/i Terhadap Wacana Amandemen UUD NRI 1945 (Survei terhadap Mahasiswa STEI ITB Angkatan 2018). Jurnal Kewarganegaraan, 5(1), 13-20.

Sakinah, R. N., \& Dewi, D. A. (2021). Implementasi Nilai-Nilai Pancasila Sebagai Karakter Dasar Para Generasi Muda Dalam Menghadapi Era Revolusi Industrial 4 . 0. Jurnal Kewarganegaraan, 5(1), 152-167.

Sakti, R. O., \& Hartanto, S. (2020). Meningkatkan Prestasi Belajar Ppkn Dengan Menggunakan Model Brain Based Learning. Jurnal Kewarganegaraan, 4(1), 38-44. https://journal.upy.ac.id/index.php/pkn/article/view/1171

Saptaningsih, R. I., \& Astuti, W. (2019). Peranan Yayasan Annisa Swasti (Yasanti) Dalam Upaya Perlindungan Dan Pemberdayaan Buruh Gendong Perempuan Di Pasar Beringharjo Yogyakarta. Jurnal Kewarganegaraan, 3(1), 46-55. https://doi.org/10.31316/jk.v3i1.512

Sigit, H., \& Andari, R. (2019). Penyelesaian Sengketa Tanah Melalui Mediasi Di Kantor Pertanahan Kabupaten Kulon Progo. Jurnal Kewarganegaraan, 3(1), 41-45. https://doi.org/10.31316/jk.v3i1.510

Susilana, Rudi dan Cepi Riyana. 2009. Media Pembelajaran: Hakikat, Pengembangan, Pemanfaatan dan Penilaian. Bandung: CV Wacana Prima.

Suyanto dan Asep Jihad, 2013. Menjadi Guru Profesional: Strategi Meningkatkan Kualifikasi dan Kualitas Guru di Era Globalisasi, Jakarta: Erlangga.

Sumarni. (2021). Model Pembelajaran Make a Match Untuk Meningkatkan HAsil Belajar Penyesuaian Diri dengan Lingkungan pada Siswa. Jurnal Kewarganegaraan, 5(1), 39-44.

Syah, Muhibbin. 2008. Psikologi Pendidikan. Bandung: Remaja Rosdakarya. Widodo, M. (2021). Upaya Meningkatkan Kompetensi Guru dalam Penguasaan Kurikulum 2013 Melalui In Service Learning. Jurnal Kewarganegaraan, 5(1), 113-119. 